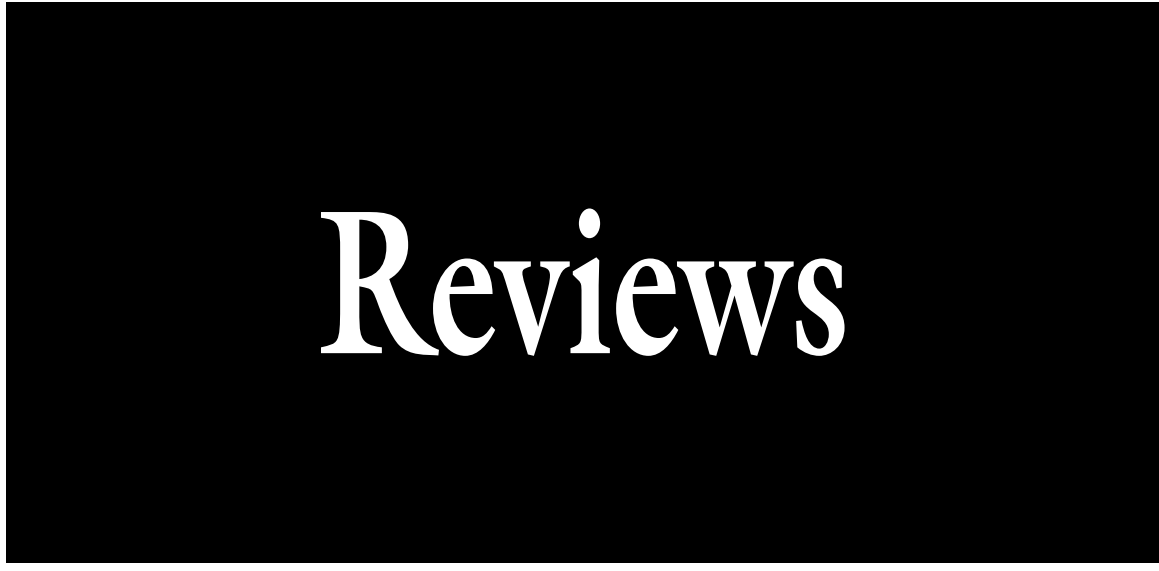

\section{Effects of Nitrogen and the Various Forms of Nitrogen on Phalaenopsis Orchid-A Review}

\author{
Yin-Tung Wang ${ }^{1,3,5}$ and Yao-Chien Alex Chang ${ }^{2,4}$
}

ADDITIONAL INDEX WORDS. moth orchid, mineral nutrition, nitrate, ammonium, urea, $\mathrm{pH}$

$\overline{\text { SUMMARY. Growers realize the importance of nitrogen }(\mathrm{N}) \text { on the vegetative growth of }}$ phalaenopsis orchids (hybrids of Phalaenopsis sp.), but often overlook its influence on reproductive growth. Low $\mathbf{N}$ may result in slow plant growth, pale-green leaves, abscission of lower leaves, and few flowers in phalaenopsis. Increasing $\mathrm{N}$ concentration up to $200 \mathrm{mg} \cdot \mathrm{L}^{-1}$ promotes leaf growth and increases flower count. High $\mathrm{N}$ concentration promotes lateral branching on the flowering stalk, thereby greatly increasing the total flower count and elevating the commercial value. It is important that $\mathbf{N}$ be continually applied during the forcing period for best flowering performance, particularly for those that had undergone international shipping. For the vegetative phalaenopsis plants that are induced to flower without being shipped internationally, the $\mathrm{N}$ that is already in the plant before spiking provides $43 \%$ and the $\mathrm{N}$ being absorbed by roots after cooling provides $57 \%$ of the total $\mathrm{N}$ in the inflorescence at time of visible bud. When insufficiently fertilized or no fertilization is applied during the forcing period, more of the existing $\mathrm{N}$ in a plant is mobilized for inflorescence development. Phalaenopsis roots can take up all three forms of $\mathrm{N}$ [i.e., nitrate $\left(\mathrm{NO}_{3}-\mathrm{N}\right)$, ammonium $\left(\mathrm{NH}_{4}-\mathrm{N}\right)$, and urea] directly. In two studies, phalaenopsis plants were supplied with the same amount of total $\mathrm{N}$ but with varying $\mathrm{NO}_{3}-\mathrm{N}$ from $100 \%, 75 \%, 50 \%, 25 \%$, to $0 \%$ (a common $\mathrm{N}$ concentration was achieved by the substitution of the respective balance with $\mathrm{NH}_{4}-\mathrm{N}$ ). Plants were smaller when receiving $75 \%$ or $100 \% \mathrm{NH}_{4}-\mathrm{N}$ with a tendency of decreasing top leaf width and whole-plant leaf spread as $\mathrm{NO}_{3}-\mathrm{N}$ decreased from $100 \%$ to $0 \%$. Spiking was delayed and spiking rate decreased when plants were grown in sphagnum moss, but not a bark mix, and received more than $50 \%$ of the $\mathrm{N}$ in $\mathrm{NH}_{4}-\mathrm{N}$. As the ratio between $\mathrm{NO}_{3}-\mathrm{N}$ and $\mathrm{NH}_{4}-\mathrm{N}$ increased, flowers became increasingly larger. The negative effects of low ratios of $\mathrm{NO}_{3}-\mathrm{N}$ to $\mathrm{NH}_{4}-\mathrm{N}$ were more severe in the second flowering cycle. When supplied with $50 \%$ or more $\mathrm{NH}_{4}-\mathrm{N}$, the absorption of cations by phalaenopsis roots declined, with reduced concentrations of calcium and magnesium in plants, while symptoms of ammonium toxicity appeared, including growth retardation, chlorotic leaves, and necrotic roots. In conclusion, adequate $\mathbf{N}$ and its continual supply during both vegetative and reproductive stages are recommended for the best growth and flowering of phalaenopsis. Since phalaenopsis plants prefer $\mathrm{N}$ in the $\mathrm{NO}_{3}-\mathrm{N}$ form, it is suggested that growers choose and apply a fertilizer with nitrate as the major $\mathrm{N}$ source.

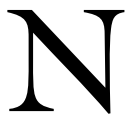

itrogen is one of the most essential mineral elements that plants need to grow and reproduce well. Low $\mathrm{N}$ can result in slow plant growth, palegreen leaves, abscission of the lower when the minerals in Johnson's solution increased from one-fourth to full strength (plants grown in sand). Using several water-soluble fertilizer formulations (Peters; Everris NA, Dublin, OH), Wang (1994, 1996) found that, as the rate of each fertilizer increased from 0.25 to $1.0 \mathrm{~g} \cdot \mathrm{L}^{-1}$ in the irrigation water, the vegetative growth, flower count, and flower size increased. When phalaenopsis is planted in sphagnum moss and using $15 \mathrm{~K}-2.2 \mathrm{P}-12.5 \mathrm{~K}(\mathrm{~N}=78 \%$ nitrate + $8 \%$ ammonium $+14 \%$ urea), as $\mathrm{N}$ concentration increased from 0 to $200 \mathrm{mg} \cdot \mathrm{L}^{-1}$, leaf span, leaf number, total leaf length, and flower count all increased (Wang, 2010) (Fig. 1). In this study, the increase in flower size as $\mathrm{N}$ rate increased could be due to the concomitant increase in potassium $(\mathrm{K})$ concentration from 0 to $166 \mathrm{mg} \cdot \mathrm{L}^{-1}$. In another study, $\mathrm{K}$ was found to result in progressively larger flower size as its rate increased from 50 to $400 \mathrm{mg} \cdot \mathrm{L}^{-1}$ (Wang, 2007). Increasing $N$ concentration to $400 \mathrm{mg} \cdot \mathrm{L}^{-1}$, in conjunction with other minerals, can be detrimental to phalaenopsis (Wang, 2003; Yao, 2007).

Nitrogen level and the length of its application may affect time of spiking in phalaenopsis. Kubota and Yoneda (1994) found that plants, which stopped receiving $\mathrm{N}$ at the beginning of September, spiked earlier than those receiving $\mathrm{N}$ until the end of September. Horio and Ichihashi (2004) and Ichihashi (2003) determined that $\mathrm{N}$ concentration at $280 \mathrm{mg} \cdot \mathrm{L}^{-1}$ caused a short delay in spiking. However, Wang (2003) found that $\mathrm{N}$ up to 400 $\mathrm{mg} \cdot \mathrm{L}^{-1}$ did not delay spiking when used as a constant feed with other required minerals for over 1 year when grown in a bark/peat mix. In another study, it was found that spiking was delayed when phalaenopsis plants were grown in sphagnum moss and never received any fertilizer (Y.T. Wang, unpublished data) (Fig. 2). At $25 \mathrm{mg} \cdot \mathrm{L}^{-1} \mathrm{~N}$, spiking and flowering were accelerated by 19 and $15 \mathrm{~d}$, respectively, compared with those of nonfertilized plants. An increase in N rate up to $200 \mathrm{mg} \cdot \mathrm{L}^{-1}$ resulted in slower spiking (8 to $10 \mathrm{~d}$ when compared with $\mathrm{N}$ at $25 \mathrm{mg} \cdot \mathrm{L}^{-1}$ ) and flowering (averaged $12 \mathrm{~d}$ when compared with $\mathrm{N}$ at $25 \mathrm{mg} \cdot \mathrm{L}^{-1}$ ), with no statistical difference among 
these higher rates, but still faster than plants that received no fertilizer.

van Noort and Dueck (2015) reported that $\mathrm{N}$ at $364 \mathrm{mg} \cdot \mathrm{L}^{-1}$ was detrimental to phalaenopsis by causing fewer double-spike plants than at 196 or $280 \mathrm{mg} \cdot \mathrm{L}^{-1} \mathrm{~N}$. The high rate of $\mathrm{N}$ at $364 \mathrm{mg} \cdot \mathrm{L}^{-1}$ rendered the flowering stems to be more susceptive to infection by Fusarium (Fusarium solani).

\section{N Rate on Flower Size}

It was well documented that flower size of phalaenopsis orchid is unaffected by $\mathrm{N}$ levels (Huang et al., 201la, 2011b; Lei, 2007; Peng, 2008; Susilo and Chang, 2014; Wang, 2003, 2010; Wang and Gregg, 1994; Y.T. Wang, unpublished data; $\mathrm{Yu}, 2012$ ). Phalaenopsis plants simply produce fewer flowers as $\mathrm{N}$ rate decreases while maintaining the flower size. Ruamrungsri et al. (2007) found that $200 \mathrm{mg} \cdot \mathrm{L}^{-1} \mathrm{~N}$ resulted in longer inflorescence length and higher flower count than $100 \mathrm{mg} \cdot \mathrm{L}^{-1}$.

During the reproductive phase, for vegetative plants that had undergone severe drying of the growing medium and been through 3-4 weeks of ocean container shipping in complete darkness at $18-20^{\circ} \mathrm{C}$, applying $\mathrm{N}$ up to $200 \mathrm{mg} \cdot \mathrm{L}^{-1}$ slightly increases flower count on the main spike. Increasing $\mathrm{N}$ also promotes lateral branching, which results in much higher total flower count (Y.T. Wang, unpublished data) (Fig. 3), as well as greener leaves (Huang et al., 2011a, 2011b; Wang et al., 2008; Y.T. Wang, unpublished data) (Fig. 4).

\section{Use of $\mathbf{N}$}

The mature leaves and roots of phalaenopsis collectively serve as a $\mathrm{N}$ pool, whereas growing leaves and inflorescences have strong demands for $\mathrm{N}$ (Susilo et al., 2013).

This article is largely based on a presentation at the 2015 Taiwan International Orchid Show and Symposium. Color photos in the online version.

${ }^{1}$ Department of Horticultural Sciences, Texas A\&M University, College Station, TX 77843

${ }^{2}$ Department of Horticulture and Landscape Architecture, National Taiwan University, Taipei 10617 , Taiwan

${ }^{3}$ Professor (retired, currently Adjunct Professor and Graduate Faculty)

${ }^{4}$ Professor

${ }^{5}$ Corresponding author. E-mail: yintung.wang@ gmail.com.

doi: 10.21273/HORTTECH03204-16
Studies consistently showed that high $\mathrm{N}$ should be continually applied during the forcing period for best flowering performance (Huang et al., 2011b; Susilo et al., 2014; Susilo and Chang, 2014; Y.T. Wang, unpublished data). In an earlier study, ending fertilization when the flowering stem had reached $10 \mathrm{~cm}$ in length had no impact on flower count or size, despite a small loss of the lower leaves (Wang, 2000).

Using $\mathrm{N}^{15}$ ( $\mathrm{N}$ with an atomic weight of 15 and an isotope of the common $\mathrm{N}$ with an atomic weight of 14) as a tracer, it was determined that $\mathrm{N}$ already existing in the plant before spiking provided $43 \%$ and the $\mathrm{N}$ absorbed by roots following spiking accounted for $57 \%$ of the total $\mathrm{N}$ that is present in the inflorescence at the visible bud stage (Susilo et al., 2014). Of the $43 \% \mathrm{~N}$ in the inflorescence, $\mathrm{N}$ absorbed during the small, medium, and large plant stages contributed $7 \%, 11 \%$, and $25 \% \mathrm{~N}$, respectively.

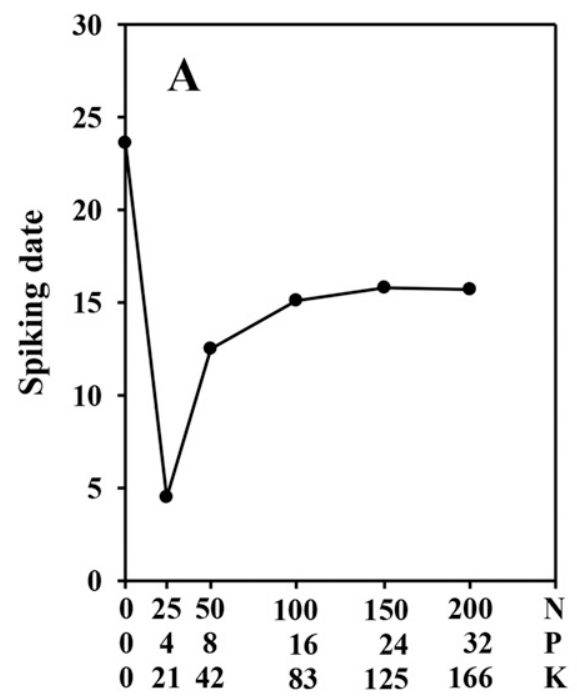

Concentration $\left(\mathrm{mg} \cdot \mathrm{L}^{-1}\right)$
When little or no fertilizer is applied during the reproductive stage (the forcing period), more existing $\mathrm{N}$ in phalaenopsis plants is mobilized and

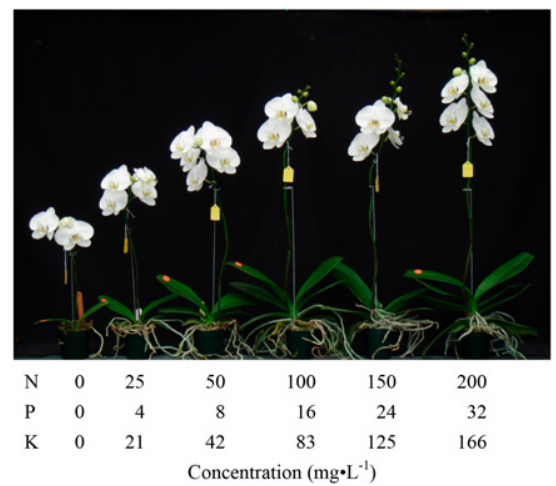

Fig. 1. Response of phalaenopsis orchid to various concentrations of nitrogen-phosphorus-potassium $(\mathrm{N}-$ $\mathrm{P}-\mathrm{K})$ fertilizer $[15 \mathrm{~N}-2.2 \mathrm{P}-12.5 \mathrm{~K}, \mathrm{~N}=$ $78 \%$ nitrate $+8 \%$ ammonium $+14 \%$ urea (Peters Professional 15-5-15 CalMag; Everris NA, Dublin, $\mathrm{OH})$ ] (Wang, 2010); $1 \mathrm{mg} \cdot \mathrm{L}^{-1}=1 \mathrm{ppm}$.

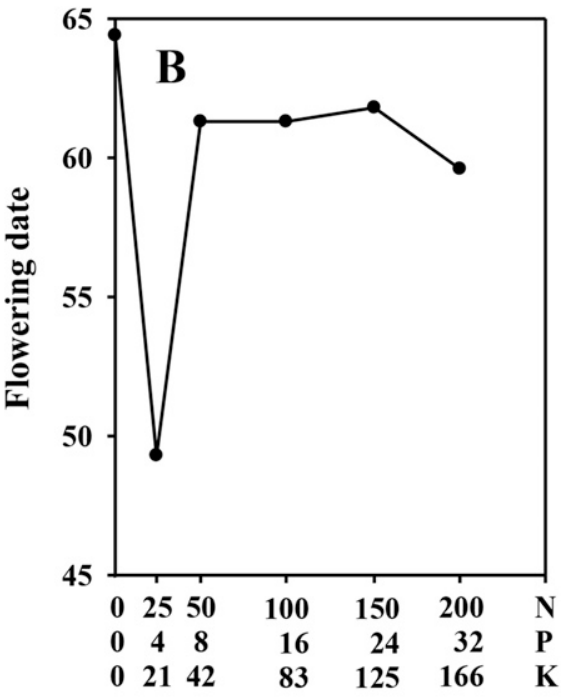

Concentration $\left(\mathbf{m g} \cdot \mathrm{L}^{-1}\right)$

Fig. 2. Effects of various concentrations of nitrogen-phosphorus-potassium (N$\mathrm{P}-\mathrm{K}$ ) fertilizer [15N-2.2P-12.5K, $\mathrm{N}=78 \%$ nitrate $+8 \%$ ammonium $+14 \%$ ureaN (Peters Professional 15-5-15 Cal-Mag; Everris NA, Dublin, $\mathrm{OH}$ )] on spiking $[\mathrm{A}(y$ axis $=$ date in October $)]$ and flowering time $[\mathrm{B}(y$ axis $=$ number of days elapsed since 1 Jan. of the following year)] of a white-flowered phalaenopsis orchid (Y.T. Wang, unpublished data); $1 \mathrm{mg} \cdot \mathrm{L}^{-1}=1 \mathrm{ppm}$.

\begin{tabular}{llll}
\hline $\begin{array}{l}\text { Units } \\
\text { To convert U.S. to SI, } \\
\text { multiply by }\end{array}$ & U.S. unit & SI unit & $\begin{array}{l}\text { To convert SI to U.S., } \\
\text { multiply by }\end{array}$ \\
\hline 1 & $\mathrm{mmho} / \mathrm{cm}$ & $\mathrm{dS} \cdot \mathrm{m}^{-1}$ & 1 \\
0.001 & $\mathrm{ppm}$ & $\mathrm{g} \cdot \mathrm{L}^{-1}$ & 1000 \\
1 & $\mathrm{ppm}$ & $\mathrm{mg} \cdot \mathrm{L}^{-1}$ & 1 \\
$\left({ }^{\circ} \mathrm{F}-32\right) \div 1.8$ & ${ }^{\circ} \mathrm{F}$ & ${ }^{\circ} \mathrm{C}$ & $\left({ }^{\circ} \mathrm{C} \times 1.8\right)+32$
\end{tabular}

Hortlechnology · April $201727(2)$ 
this is sufficient to meet most of the $\mathrm{N}$ demand for inflorescence development to make an acceptable commercial crop if plants had been fertilized well during the vegetative growing period (Susilo and Chang, 2014). However, the foliage may appear the less appealing pale green (Fig. 4) and one or more lower leaves may abscise.

Symptoms of $\mathrm{N}$ deficiency in phalaenopsis first occur in the lower leaves due to its easy mobility and translocation out of the older leaves under low or deficient conditions to support the new growth (Huang et al., 201la, 2011b; Wang, 2010; Y.T. Wang, unpublished data). The symptoms can be yellowing and abscission of the basal leaves, which becomes progressively more severe with the opening of more flowers (Wang, 2010; Wang et al., 2006; Y.T. Wang, unpublished data).

\section{Forms and Uptake of $\mathrm{N}$}

Nitrogen comes in various forms, such as $\mathrm{NO}_{3}-\mathrm{N}, \mathrm{NH}_{4}-\mathrm{N}$, and urea $\left[\mathrm{CO}\left(\mathrm{NH}_{2}\right)_{2}\right]$. Most complete fertilizers carry two or all three forms of $\mathrm{N}$ in various proportions. $\mathrm{NH}_{4}-\mathrm{N}$ and urea are treated collectively as the "ammoniacal N."

Roots of phalaenopsis are the major organs responsible for the uptake of mineral nutrients in phalaenopsis. The amount of mineral nutrients that is absorbed through the foliage is limited and not enough to support good vegetative growth and flowering (Huang et al., 201 lb; Susilo et al., 2013; Wang, 2010).

Phalaenopsis roots can take up all three forms of $\mathrm{N}$ directly. Burgeff (1936) showed that $\mathrm{NO}_{3}-\mathrm{N}$ was best used by orchids (Orchidaceae) that attach to other plants or objects in light. Many tropical orchid species fall into this group. $\mathrm{NH}_{4}-\mathrm{N}$ was necessary for growth in darkness or in light by the more heterotrophic (organisms that cannot fix carbon and use organic carbon for growth) and saprophytic (organisms that live on dead or decomposing matter) species. Using $\mathrm{N}^{15}$, Trépanier et al. (2009) demonstrated that, for phalaenopsis plantlets in tissue-culture flasks, urea and $\mathrm{NH}_{4}-\mathrm{N}$ are the two preferred forms of $\mathrm{N}$ absorbed, with 47\% and $41 \%$, respectively, of the total amount $\mathrm{N}$ taken up from the cultural medium.

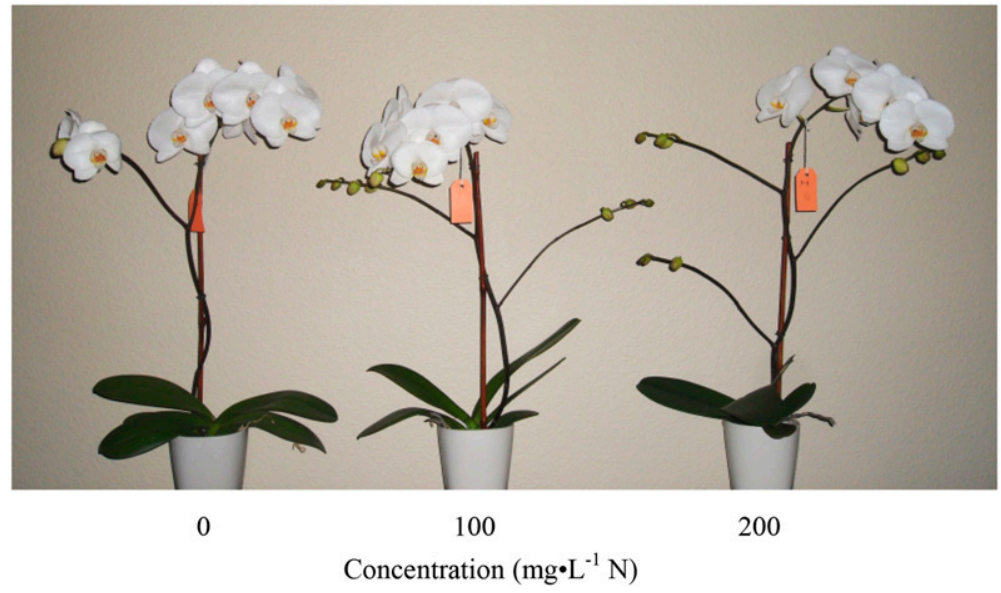

Fig. 3. Effects of increasing nitrogen $(\mathrm{N})$ concentration from 0 to $200 \mathrm{mg} \cdot \mathrm{L}^{-1}$ during the reproductive stage on lateral branching and total flower count of phalaenopsis orchid. Plants were grown in sphagnum moss and undergone shipping in an ocean container for 3 weeks in complete darkness at between 18 and $20{ }^{\circ} \mathrm{C}\left(64.4\right.$ and $\left.68.0^{\circ} \mathrm{F}\right)$ before being forced in a commercial greenhouse (Y.T. Wang, unpublished data); $1 \mathrm{mg} \cdot \mathrm{L}^{-1}=1 \mathrm{ppm}$.

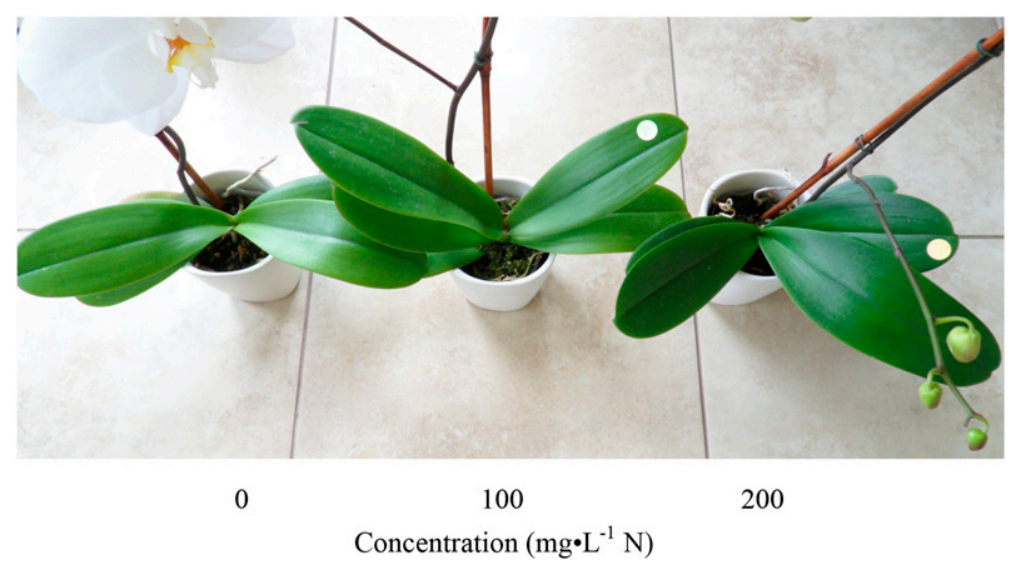

Fig. 4. Effects of increasing nitrogen $(\mathrm{N})$ concentration from 0 to $200 \mathrm{mg} \cdot \mathrm{L}^{-1}$ during the reproductive period on leaf color of phalaenopsis orchid. Plants were grown in sphagnum moss and undergone shipping in an ocean container for 3 weeks in complete darkness at between 18 and $20{ }^{\circ} \mathrm{C}\left(64.4\right.$ and $\left.68 .{ }^{\circ} \mathrm{F}\right)$ before being forced in a commercial greenhouse (Y.T. Wang, unpublished data); $1 \mathrm{mg} \cdot \mathrm{L}^{-1}=1 \mathrm{ppm}$.

\section{Forms of N Affect Medium pH}

When urea is applied to the growing medium, it is quickly converted to $\mathrm{NH}_{4}$ ion $\left(\mathrm{NH}_{4}^{+}\right)$and then to $\mathrm{NO}_{3}$ ion $\left(\mathrm{NO}_{3}^{-}\right)$by microorganisms, except at low temperatures. When $\mathrm{NH}_{4}{ }^{+}$is converted to $\mathrm{NO}_{3}{ }^{-}$, protons [hydrogen ions $\left(\mathrm{H}^{+}\right)$] are released in the process, which lowers the $\mathrm{pH}$ of the growing medium (more acidic). When $\mathrm{NH}_{4}{ }^{+}$is absorbed by the roots, protons are released from the roots to balance the electrical charge in the root and this process causes the acidification of the

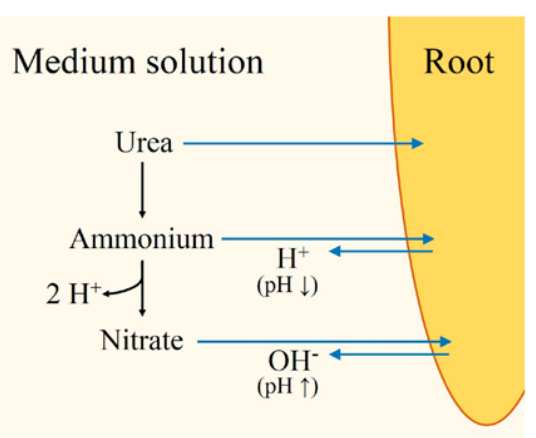

Fig. 5. Effects of various forms of nitrogen on the $\mathrm{pH}$ of growing media $\left(\mathrm{H}^{+}=\right.$hydrogen ion or proton, $\mathrm{OH}^{-}=$hydroxyl ion $)$. 
surrounding growing medium (Fig. $5)$. Therefore, $\mathrm{NH}_{4}-\mathrm{N}$ is a doubleedged sword to cause the acidification of the growing medium.

When $\mathrm{NO}_{3}^{-}$is absorbed, roots release hydroxyl ions $\left(\mathrm{OH}^{-}\right)$, which neutralize the existing protons in the medium, resulting in increased $\mathrm{pH}$ [more basic (Fig. 5)]. Therefore, fertilizers that contain large proportions of $\mathrm{N}$ as ammoniacal- $\mathrm{N}$ are called acidic fertilizers, whereas those containing high percentages of $\mathrm{NO}_{3}-\mathrm{N}$ are called basic fertilizers. Carefully selecting fertilizers can be a tool for managing the root-zone $\mathrm{pH}$ at a desirable level or to correct the $\mathrm{pH}$ of the growing medium. However, this statement does not hold entirely true in the case of growing the phalaenopsis. A study demonstrated that the phalaenopsis root is the main cause of $\mathrm{pH}$ drop in the sphagnum moss growing medium, not fertilizer alone (Yen et al., 2011) (Fig. 6). In addition, the $\mathrm{pH}$ of the moss in phalaenopsis containers is usually around 3 and it is difficult to bring the $\mathrm{pH}$ up in commercial production, even when a basic fertilizer is used for an extended period of time (Wang, 2010) (Fig. 7), or when the initial $\mathrm{pH}$ of the moss was adjusted by liming (Yen, 2010). Despite of the low medium $\mathrm{pH}$ around 3 , phalaenopsis seems to grow well with no signs of mineral phytotoxicity. In contrast, snapdragon (Antirrbinum majus) and marigold (Tagetes sp.) plants exhibit severe symptoms of iron and manganese toxicity at a $\mathrm{pH}$ just below 6 (Brubaker, 2016). Pothos ivy (Epipremnum aureum) also develops severe speckling on its lower, old leaves at low medium $\mathrm{pHs}$ as a result of mineral toxicity (Wang, 1991).

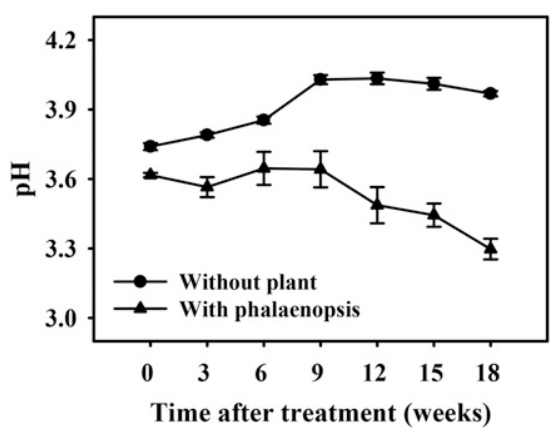

Fig. 6. Effect of phalaenopsis orchid Sogo Yukidian 'V3' on the $\mathrm{pH}$ of sphagnum moss medium (Yen et al., 2011).

\section{Nitrate vs. Ammonium N}

Two studies were independently conducted to determine how the ratio of $\mathrm{NO}_{3}-\mathrm{N}$ to $\mathrm{NH}_{4}-\mathrm{N}$ would affect phalaenopsis. In the U.S. study (Wang, 2008), cloned plants of phalaenopsis Taisuco Kaaladian were grown in a mix consisting of 3 parts medium grade douglas fir (Psendotsuga menziesii) bark and 1 part each of perlite and long-fiber peat (by volume) or in sphagnum moss. In the fertilizer solutions, the total $\mathrm{N}$ varied from $100 \%$, $75 \%, 50 \%, 25 \%$, to $0 \%$ as $\mathrm{NO}_{3}-\mathrm{N}$ and the balance was from $\mathrm{NH}_{4}-\mathrm{N}\left(\mathrm{NH}_{4}{ }^{+}\right.$or ammonium only, no urea). Plants that were grown in sphagnum moss produced more leaves than those in the bark mix (4.5 vs. 3.4), regardless of the $\mathrm{NO}_{3}-\mathrm{N}$ to $\mathrm{NH}_{4}-\mathrm{N}$ ratio. The rate of leaf production did not differ across the various ratios of $\mathrm{N}$ sources in either medium.

Phalaenopsis plants in both media were smaller when receiving $25 \%$ or $0 \%$ of $\mathrm{N}$ as $\mathrm{NO}_{3}-\mathrm{N}$ (Wang, 2008) (Fig. 8). There is a tendency of decreasing top leaf width and whole-plant

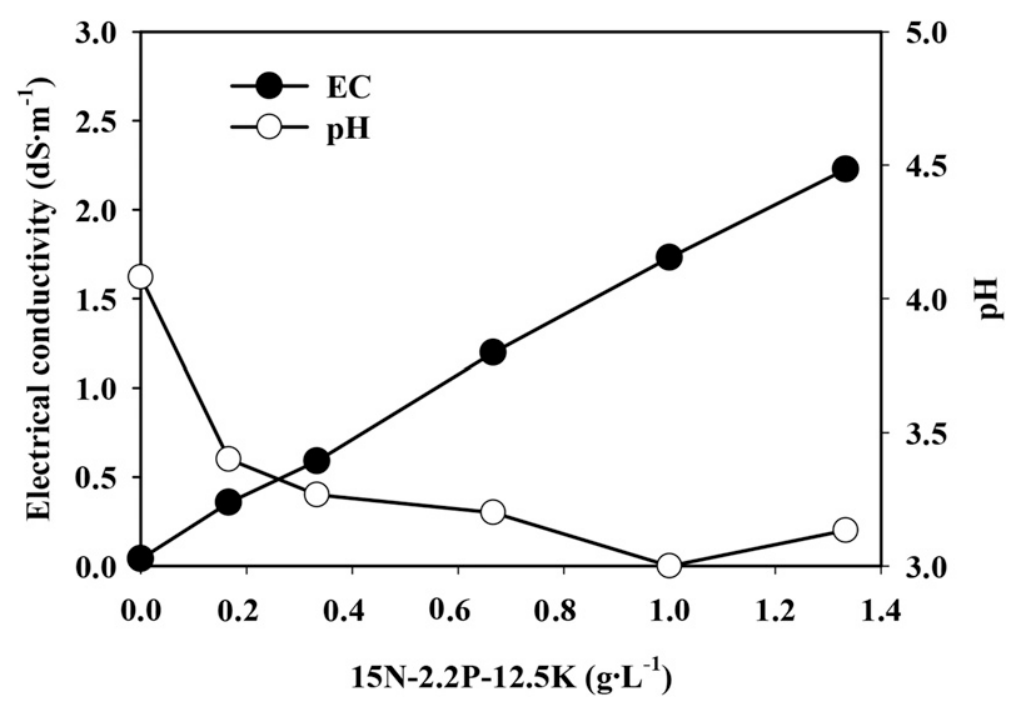

Fig. 7. Effect of nitrogen-phosphorus-potassium (N-P-K) fertilizer [15N-2.2P$12.5 \mathrm{~K}$ fertilizer, $\mathrm{N}=78 \%$ nitrate $+8 \%$ ammonium $+14 \%$ urea (Peters Professional 15-5-15 Cal-Mag; Everris NA, Dublin, $\mathrm{OH})]$ on the electrical conductivity (EC) and the $\mathrm{pH}$ of sphagnum moss medium used for growing phalaenopsis orchid for over 18 months (Wang, 2010); $1 \mathrm{~g} \cdot \mathrm{L}^{-1}=1000 \mathrm{ppm}$, $1 \mathrm{dS} \cdot \mathrm{m}^{-1}=1 \mathrm{mmho} / \mathrm{cm}$.

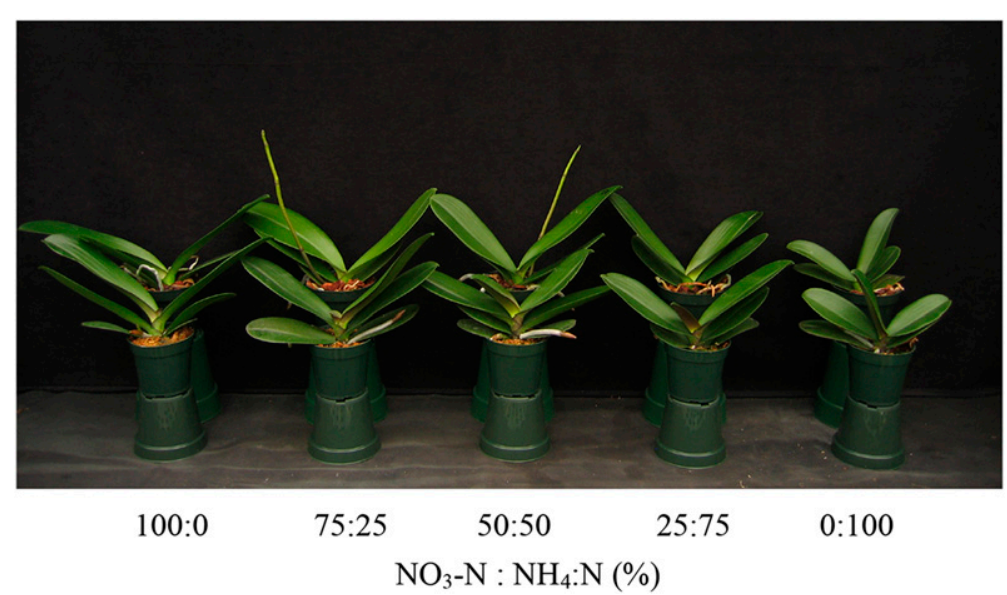

Fig. 8. A clone of phalaenopsis orchid Taisuco Kaaladian receiving $100 \%, 75 \%$, $50 \%, 25 \%$, and $0 \%$ nitrate nitrogen $\left(\mathrm{NO}_{3}-\mathrm{N}\right)$. The balance is ammonium $\mathrm{N}\left(\mathrm{NH}_{4}-\mathrm{N}\right)$; no urea was used. Plants in the front row were planted in sphagnum moss; back row planted in a medium consisting of $60 \%$ medium-size douglas fir bark, $20 \%$ perlite, and $20 \%$ coarse sphagnum peat (Wang, 2008). 
Table 1. Effects of nitrate $\left(\mathrm{NO}_{3}{ }^{-}\right)$to ammonium $\left(\mathrm{NH}_{4}{ }^{+}\right)$nitrogen ratio on spiking and flower count on phalaenopsis. Research was conducted independently in two countries and at different times. Plants used in the U.S. study were grown in sphagnum moss or a bark mix. Those used in Taiwan were planted in sphagnum only.

\begin{tabular}{|c|c|c|c|c|}
\hline \multirow[b]{3}{*}{$\mathrm{NO}_{3}: \mathrm{NH}_{4}(\%)$} & \multicolumn{2}{|c|}{ United States } & \multirow{2}{*}{\multicolumn{2}{|c|}{ Taiwan }} \\
\hline & Spiking & & & \\
\hline & Sphagnum moss & Bark mix ${ }^{z}$ & Spiking (\%) & Flowers (no.) \\
\hline 100:0 & 75 & 100 & 91 & 19 \\
\hline $75: 25$ & 83 & 100 & 95 & 19 \\
\hline $50: 50$ & 71 & 100 & 86 & 16 \\
\hline $25: 75$ & 58 & 100 & 67 & 12 \\
\hline $0: 100$ & 8 & 91 & 10 & 9 \\
\hline
\end{tabular}

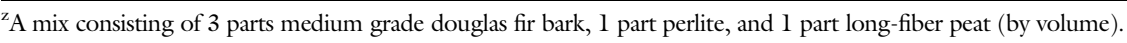

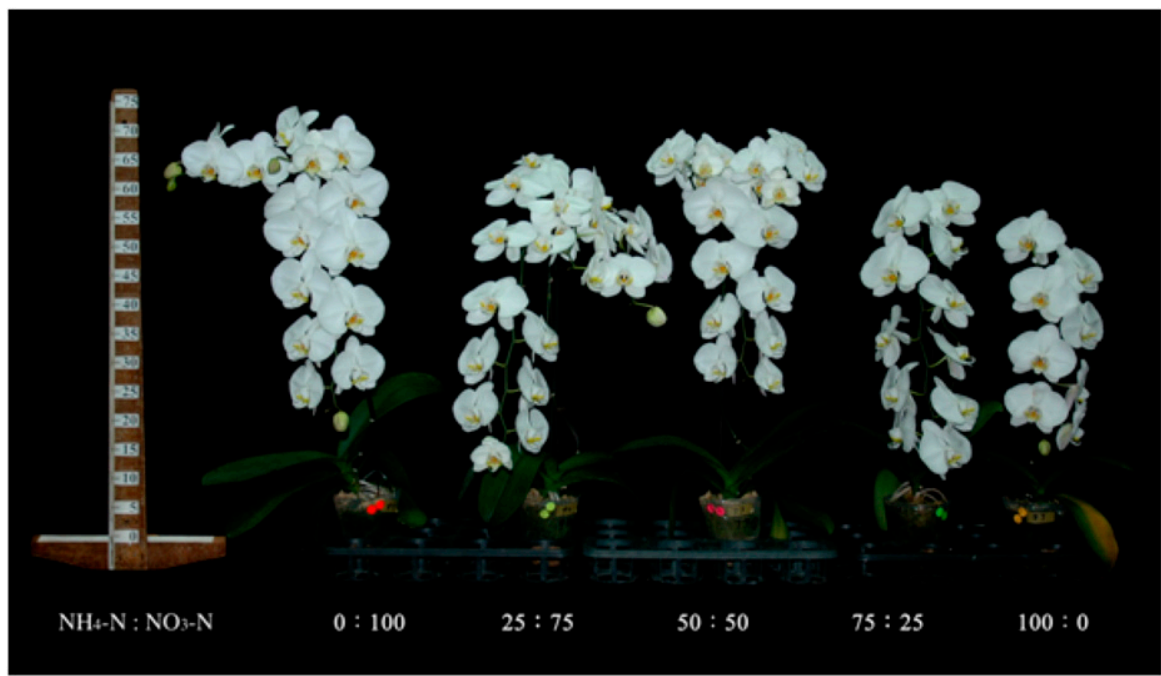

Fig. 9. Effect of ammonium nitrogen $\left(\mathrm{NH}_{4}-\mathrm{N}\right)$ to nitrate $\mathrm{N}\left(\mathrm{NO}_{3}-\mathrm{N}\right)$ ratio $(\%$ of each) on leaf growth and flower quality in phalaenopsis orchid Sogo Yukidian 'V3' during the second flowering cycle (Y.C.A. Chang and Y.C. Peng, unpublished data).

leaf spread as $\mathrm{NO}_{3}-\mathrm{N}$ decreased from $100 \%$ to $0 \%$. Applying $100 \% \mathrm{NH}_{4}-\mathrm{N}$ to the bark medium or $75 \%$ and $100 \%$ $\mathrm{NH}_{4}-\mathrm{N}$ to moss resulted in shorter top leaves than those in other treatments. Phalaenopsis plants in the bark mix spiked 10 to $14 \mathrm{~d}$ earlier than those planted in moss. Plants receiving $50 \%$ or more $\mathrm{NO}_{3}-\mathrm{N}$ spiked earlier and had higher percentages of the plants that produced flowers (Wang, 2008) (Fig. 8). Nearly all of the plants in the bark mix produced flowers (91\% for those receiving $100 \% \mathrm{NH}_{4}-\mathrm{N}$ ), whereas only $8 \%$ in moss receiving $100 \% \mathrm{NH}_{4}-\mathrm{N}$ spiked (Table 1). As the ratio between $\mathrm{NO}_{3}-\mathrm{N}$ and $\mathrm{NH}_{4}-\mathrm{N}$ increased, flowers became increasingly larger. In the bark mix, flowers on plants receiving $75 \% \mathrm{NO}_{3}-\mathrm{N}$ were $36 \%$ larger in area than those on plants receiving $100 \% \mathrm{NH}_{4}-\mathrm{N}$ (Wang, 2008).
A more detailed study (Peng et al., 2010) in Taiwan used phalaenopsis Sogo Yukidian 'V3' and was carried through two flowering cycles (20 months). Two experiments were conducted using young plants $(20 \mathrm{~cm}$ leaf span) or mature plants $(32 \mathrm{~cm}$ leaf span). The time to spiking and to flower opening of the mature plants was unaffected by $\mathrm{NH}_{4}-\mathrm{N}$ to $\mathrm{NO}_{3}-\mathrm{N}$ ratio in both flowering cycles. However, the spiking percentage, the flower count, and the diameter and length of the stalk in the second flowering cycle increased when plants received $50 \%$ or more $\mathrm{NO}_{3}-\mathrm{N}$. Only $10 \%$ of the phalaenopsis plants receiving $100 \% \mathrm{NH}_{4}-\mathrm{N}$ spiked in the second season (Table l). Plant fresh weight, leaf number, and leaf area of both young and mature plants decreased with decreasing $\mathrm{NO}_{3}-\mathrm{N}$ to $\mathrm{NH}_{4}-\mathrm{N}$ ratio (Peng et al., 2010)
(Fig. 9). When supplied with 50\% or more $\mathrm{NH}_{4}^{+}$, the absorption of cations by phalaenopsis roots declined; and, hence, the concentration of calcium and magnesium in plants decreased, while symptoms of $\mathrm{NH}_{4}{ }^{+}$ toxicity occurred, such as growth retardation, chlorotic leaves, and necrotic roots.

\section{Conclusions}

Phalaenopsis plants grow and flower well when given 200-280 $\mathrm{mg} \cdot \mathrm{L}^{-1} \mathrm{~N}$ during both the vegetative and reproductive periods. Phalaenopsis does not grow and flower well with $100 \% \mathrm{NH}_{4}-\mathrm{N}$, particularly when planted in sphagnum moss, and must be fertilized with no less than $50 \%$ and preferably $75 \% \mathrm{NO}_{3}-\mathrm{N}$ in the total fertilizer $\mathrm{N}$ to achieve the highest percentage of spiking, high degree of lateral branching on the flower stalk, as well as increased flower count, flower size, leaf number, and plant fresh weight. High $\mathrm{N}$ must be applied during the reproductive period for best flowering.

For the commonly used $20 \mathrm{~N}-$ 8.8P-16.6K fertilizers, the $\mathrm{NO}_{3}-\mathrm{N}$ varies from $11 \%$ to $28 \%$ of its total $\mathrm{N}$ (depending on the brand), whereas the $20 \mathrm{~N}-4.4 \mathrm{P}-16.6 \mathrm{~K}$ (e.g., Peters Professional 20-10-20) has 60\%, the $15 \mathrm{~N}-2.2 \mathrm{P}-12.5 \mathrm{~K}$ (e.g., Peters Excel 15-5-15 Cal-Mag) has 79\%, and the $15 \mathrm{~N}-2.2 \mathrm{P}-20.8 \mathrm{~K}$ (e.g., Peters Professional $15-5-25$ ) has $71 \%$ of their $\mathrm{N}$ as $\mathrm{NO}_{3}-\mathrm{N}$. The $30 \mathrm{~N}-4.4 \mathrm{P}-8.3 \mathrm{~K}$ (e.g., Peters Professional 30-10-10) is not recommended for growing phalaenopsis in sphagnum moss due to its $\mathrm{N}$ coming mainly from urea $(83 \%)$ and $\mathrm{NH}_{4}-\mathrm{N}(7 \%)$, as well as its low K. A complete soluble fertilizer with at least $50 \%$ of its $\mathrm{N}$ in $\mathrm{NO}_{3}-\mathrm{N}$ form is highly recommended, provided its $\mathrm{K}$ level is adequate.

\section{Literature cited}

Brubaker, V. 2016. Feast on famine: Managing iron deficiency and toxicity. Grower Talks 79(10):30-32.

Burgeff, H. 1936. Samenkeimung der Orchideen und Entwicklung ihrer Keimpflanzen mit einem Anhang über praktische Orchideenanzucht. G. Fisher, Jena, Germany.

Horio, S. and S. Ichihashi. 2004. Control of spiking in Phalaenopsis by nitrogen application under lower temperature. Proc. Nagoya Intl. Orchid Congr. p. 13-15. 
Huang, C.C., S.C. Yu, C.Y. Tsai, H.S. Huang, and G.P. Chang. 201 la. Effect of fertilization after simulated export transportation on flower quality and leaf color of Phalaenopsis Sogo Yukidian 'V3'. J. Taiwan Soc. Hort. Sci. 57:133142. (in Chinese with English abstract).

Huang, C.C., S.C. Yu, C.Y. Tsai, H.S. Huang, and G.P. Chang. 2011b. Effect of fertilization on flower and leaf quality of simulate transported Phalaenopsis Sogo Yukidian 'V3'. Tech. Serv. Qrtly. Bul. Taiwan Agr. Res. Inst. 87:18-23. (in Chinese).

Ichihashi, S. 2003. Effects of nitrogen application on leaf growth, inflorescence development, and flowering in Phalaenopsis. Bul. Aichi Univ. Educ. $52: 35-42$.

Kubota, S. and K. Yoneda. 1994. Effect of time of nitrogen application on growth and flowering in Phalaenopsis plant. Trop. Agr. 38:73-77.

Lee, N. and G.M. Lin. 1987. Controlling the flowering of Phalaenopsis. Proc. Symp. Forcing Cult. Hort. Crops, p. 27-44. Taichung District Agr. Improvement Sta., Taichung, Taiwan (in Chinese with English abstract).

Lei, S.Y. 2007. Changes of mineral composition and fertilizer requirement of Phalaenopsis during reproductive stages. MS Thesis, National Taiwan Univ., Taipei, Taiwan (in Chinese with English abstract).

Peng, Y.C. 2008. The uptake, partitioning, and uses of nitrogen in Phalaenopsis Sogo Yukidian 'V3'. MS Thesis, National Taiwan Univ., Taipei, Taiwan (in Chinese with English abstract)

Peng, Y.C., R.S. Chung, S.B. Ho, and Y.C.A. Chang. 2010. Ammonium- to nitrate-nitrogen ratio affects vegetative and reproductive growth in Phalaenopsis Sogo Yukidian 'V3'. J. Taiwan Soc. Hort. Sci. 56:45-56. (in Chinese with English abstract).

Ruamrungsri, S., P. Samanit, T. Pornsawatchai, N. Potapohn, and S. Fukai. 2007. Effect of fertilizer application on nutritional concentrations and flower quality of Phalaenopsis hybrid. Acta Hort. 755:495498.

Susilo, H. and Y.C.A. Chang. 2014. Nitrogen source for inflorescence development in Phalaenopsis: II. Effect of reduced fertilizer level on stored nitrogen use. J. Amer. Soc. Hort. Sci. 139:76-82.

Susilo, H., Y.C. Peng, and Y.C.A. Chang. 2014. Nitrogen source for inflorescence development in Phalaenopsis: I. Relative significance of stored and newly absorbed nitrogen. J. Amer. Soc. Hort. Sci. 139:69-75.

Susilo, H., Y.C. Peng, S.C. Lee, Y.C. Chen, and Y.C.A. Chang. 2013. The uptake and partitioning of nitrogen in $\mathrm{Pha}$ laenopsis Sogo Yukidian 'V3' as shown by ${ }^{15} \mathrm{~N}$ as a tracer. J. Amer. Soc. Hort. Sci. 138:229-237.

Trépanier, M., M.-P. Lamy, and B. Dansereau. 2009. Phalaenopsis can absorb urea directly through their roots. Plant Soil 319:95-100.

van Noort, F. and T. Dueck. 2015. Influence of fertilization and a high daily light integral on the growth and flowering of Phalaenopsis. Acta Hort. 1078:93-98.

Wang, F.N., K.H. Chang, T.F. Hsieh, and R.S. Chung. 2008. Effects of three fertilizer formulae on growth and nutrient uptake of Phalaenopsis amabilis var. formosana. J. Taiwan Soc. Hort. Sci. 54:231-246. (in Chinese with English abstract).

Wang, Y.T. 1991. Maximizing growth of pothos ivy. Greenhouse Manager 9(9):74 76,78 .

Wang, Y.T. 1994. Medium and fertilizer affect the performance of Phalaenopsis orchids during two flowering cycles. HortScience 29:269-271.

Wang, Y.T. 1996. Effects of six fertilizers on vegetative growth and flowering of Phalaenopsis orchids. Sci. Hort. 65:191197.
Wang, Y.T. 2000. Impact of a high phosphorus fertilizer and time of termination of fertilization on flowering of a hybrid moth orchid. HortScience 35:60-62.

Wang, Y.T. 2003. Effects of $\mathrm{N}$ and $\mathrm{P}$ concentration on growth and flowering of the Phalaenopsis orchid. HortScience 38:746 (abstr.).

Wang, Y.T. 2007. Potassium nutrition affects Phalaenopsis growth and flowering. HortScience 42:1563-1567.

Wang, Y.T. 2008. High $\mathrm{NO}_{3}-\mathrm{N}$ to $\mathrm{NH}_{4}-\mathrm{N}$ ratios promote growth and flowering of a hybrid Phalaenopsis in two root substrates. HortScience 43:350-353.

Wang, Y.T. 2010. Phalaenopsis mineral nutrition. Acta Hort. 878:321-334.

Wang, Y.T. and L.L. Gregg. 1994. Medium and fertilizer affect the performance of Phalaenopsis orchids during two flowering cycles. HortScience 29:269-271.

Wang, Y.X., Y.M. Chen, and T.M. Shen. 2006. Effects of shipping temperature and durations on post-shipping growth of sphagnum moss grown Phalaenopsis. J. Taiwan Soc. Hort. Sci. 52:311-320. (in Chinese with English abstract).

Yao, H.Y. 2007. Applying pour-through medium solution testing method on Phalaenopsis grown with sphagnum moss. MS Thesis, National Taiwan Univ., Taipei (in Chinese with English abstract).

Yen, W.Y. 2010. The acidification of sphagnum moss medium in Phalaenopsis cultivation. MS Thesis, National Taiwan Univ., Taipei, Taiwan (in Chinese with English abstract).

Yen, W.Y., Y.C.A. Chang, and Y.T. Wang. 2011. The acidification of sphagnum moss substrate during Phalaenopsis cultivation. HortScience 46:1022-1026.

Yu, Y.C. 2012. Growth response and gene expression profiling in Phalaenopsis under nitrogen, phosphorus, and potassium deficiency stress. MS Thesis. National Taiwan Univ., Taipei, Taiwan. 